\title{
KAJIAN IZIN PENGGUNAAN TENAGA KERJA ASING DALAM PERATURAN PRESIDEN NOMOR 20 TAHUN 2018*
}

\author{
Oleh: \\ Putu Genta Prayoga Mahardika** \\ I Made Sarjana*** \\ Program Kekhususan Hukum Bisnis \\ Fakultas Hukum Universitas Udayana
}

\begin{abstract}
ABSTRAK
Dikeluarkannya Perpres Nomor 20 Tahun 2018 yang didalamnya mengatur mengenai penyederhanaan izin penggunaan TKA diharapkan dapat mendongkrak investasi asing di Indonesia, tetapi dalam penerapannya Perpres tersebut menimbulkan permasalahan hukum. Beberapa pasal dalam Perpres tersebut dinilai bertentangan dengan ketentuan dalam UU No. 13 Tahun 2003. Di sisi lain, Perpres tersebut dianggap dapat mempersempit kesempatan memperoleh pekerjaan bagi tenaga kerja lokal. Tujuan penulisan jurnal ini adalah untuk mengetahui bentuk izin penggunaan TKA dalam Perpres No. 20 Tahun 2018 dan mengetahui apakah ketentuan terkait perizinan dalam Perpres tersebut telah sesuai dengan peraturan dasarnya yakni UU No. 13 Tahun 2003. Metode penelitian dalam penulisan jurnal ini menggunakan metode normatif. Hasil penelitian menunjukkan terdapat penyederhanaan bentuk perizinan dalam Perpres Nomor 20 Tahun 2018, seperti ditetapkannya RPTKA sebagai izin kerja, waktu proses pengurusan izin yang dikurangi dan jangka waktu berlakunya izin didasarkan pada perjanjian kerja. Di samping itu, Pasal 9 serta Pasal 10 Ayat 1 huruf a dalam Perpres Nomor 20 Tahun 2018 bertentangan dengan ketentuan Pasal 43 Ayat 1 dan Pasal 43 Ayat 3 UU No. 13 Tahun 2003.
\end{abstract}

Kata Kunci : Perizinan, Tenaga Kerja Asing, Ketenagakerjaan

\footnotetext{
* Karya ilmiah ini merupakan ringkasan di luar skripsi.

** Putu Genta Prayoga Mahardika merupakan mahasiswa Fakultas Hukum Universitas Udayana.

${ }^{* * *}$ I Made Sarjana merupakan Dosen Fakultas Hukum Universitas Udayana.
} 


\begin{abstract}
The issuance of Presidential Regulation Number 20 Year 2018 which regulates the simplification of permits to use Foreign Workers is expected to boost foreign investment in Indonesia, but in its implementation the Presidential Regulation raises legal problems. Several articles in the presidential regulation are considered to be contrary to the provisions in Law No. 13 of 2003. On the other hand, the Presidential Regulation is considered to be able to narrow the opportunity to obtain employment for local Workers. The purpose of writing this journal is to find out the form of permit to use foreign workers in Presidential Regulation No. 20 of 2018 and find out whether the provisions related to licensing in the Presidential Regulation are in accordance with the basic regulations, namely Law No. 13 of 2003. The research method in writing this journal uses normative methods. The results of the study indicate that there is a simplification of the licensing form in Presidential Regulation No. 20 of 2018, such as the stipulation of the RPTKA as a work permit, the processing time for processing permits is reduced and the period of validity of the permit based on the Work Agreement. In addition, Article 9 and Article 10 paragraph 1 letter $a$ in Presidential Regulation Number 20 of 2018 contradict the provisions of Article 43 Paragraph 1 and Article 43 Paragraph 3 of Law No. 13 of 2003.
\end{abstract}

\title{
Keywords: Licensing, Foreign Workers, Employment
}

\section{PENDAHULUAN}

\subsection{Latar Belakang}

Istilah tenaga kerja atau pekerja merupakan pengganti istilah buruh yang digunakan pada zaman penjajahan Belanda ${ }^{1}$. Buruh adalah setiap orang yang sifat pekerjaannya kasar, yang pada zaman penjajahan Belanda disebut dengan Blue Collar ${ }^{2}$. Disamping istilah tenaga kerja, dikenal juga istilah tenaga kerja asing (selanjutnya disebut TKA) yakni, orang yang bukan merupakan warga negara

\footnotetext{
${ }^{1}$ I Made Udiana, 2016, Kedudukan Dan Kewenangan Pengadilan Hubungan Industrial, Udayana University Press, Denpasar, h. 43.

${ }^{2}$ I Made Udiana, 2018, Industrialisasi Dan Tanggungjawab Pengusaha Terhadap Tenaga Kerja Terlibat Hukum, Udayana University Press, Denpasar, h. 70.
} 
Indonesia, yang bekerja baik dalam maupun di luar hubungan kerja guna menghasilkan jasa dan/atau barang. ${ }^{3}$

Di Indonesia, pengaturan terkait penggunaan TKA didasarkan pada Undang-Undang No. 13 Tahun 2003 (selanjutnya disebut UU No. 13 Tahun 2003), yaitu diatur dalam Pasal 42 sampai 49. Untuk membatasi masuknya TKA ke Indonesia diterapkanlah prosedur perizinan yakni berupa Rencana Penggunaan Tenaga Kerja Asing (selanjutnya disebut RPTKA) dan Izin Mempekerjakan Tenaga Kerja Asing (selanjutnya disebut IMTA), diberlakukannya prosedur izin tersebut merupakan upaya pemerintah Indonesia untuk mengoptimalisasi pendayagunaan tenaga kerja Indonesia (selanjutnya disebut TKI) serta sebagai jaring pengaman masuknya TKA.

Pada tanggal 29 Maret 2018, Peraturan Presiden Nomor 20 Tahun 2018 tentang Penggunaan Tenaga Kerja Asing (selanjutnya disebut Perpres No. 20 Tahun 2018) resmi diundangkan, dalam Perpres tersebut diatur mengenai penyederhanaan bentuk perizinan untuk mempekerjakan TKA yang diharapkan dapat meningkatkan investasi asing, yakni investasi langsung yang dapat memberikan dampak positif seperti alih pengetahuan dan teknologi. ${ }^{4}$ Seperti yang diketahui Indonesia memiliki keunggulan komparatif5. Jadi, untuk mendukung keunggulan tersebut diperlukan modal yang bersumber dari Investasi. Di samping itu, untuk mewujudkan kesejahteraan

${ }^{3}$ Abdul Khakim, 2014, Dasar-Dasar Hukum Ketenagakerjaan Indonesia, PT Citra Aditya Bakti, Bandung, h. 24.

${ }^{4}$ Hendrik Budi Untung, 2017, Hukum Investasi, Sinar Grafika, Jakarta, h.16.

${ }^{5}$ Putu Tuni Cakabawa Landra, 2018, Hukum Investasi Dalam Industrialisasi Kepariwisataan Bali, Jurnal Magister Hukum Udayana, Vol. 7, No. 1, https://ojs.unud.ac.id/index.php/jmhu/article/view/37685/24230,diakses tanggal 29 Mei 2019, h. 102. 
umum perlu dilakukan upaya pembangunan nasional. 6 Jadi, Investasi dapat berperan sebagai sumber modal untuk pembangunan nasional.

Penyederhanaan izin dalam Perpres No. 20 Tahun 2018 cenderung memudahkan TKA untuk masuk ke Indonesia. Disisi lain angka pengangguran di Indonesia masih tinggi, sehingga Perpres tersebut dipandang dapat mempersempit kesempatan TKI untuk mendapat pekerjaan. Fakta dilapangan menunjukkan marak dilakukannya aksi demonstrasi oleh serikat pekerja yang menuntut agar Perpres No. 20 Tahun 2018 tersebut dicabut. Penyederhanaan izin mempekerjakan TKA belum tentu menjamin dapat mendongkrak Investasi, karena faktor lain yang juga harus diperhatikan untuk mendongkrak Investasi adalah stabilitas politik dan ekonomi suatu negara serta kepastian hukum, baik substansi hukum, kinerja aparatur hukum, budaya hukum dan penegakan hukum. ${ }^{7}$

\subsection{Rumusan Masalah}

Rumusan masalah yang dapat ditarik dari latar belakang diatas adalah sebagai berikut;

1. Bagaimana bentuk perizinan penggunaan TKA dalam Perpres No. 20 Tahun 2018 ?

2. Apakah pengaturan izin penggunaan TKA dalam Perpres No. 20 Tahun 2018 sudah sesuai dengan ketentuan dalam UU No. 13 Tahun 2003?

\footnotetext{
${ }^{6}$ Noor Faiz, 2017, Korelasi Pengaturan Upah Dengan Investasi Di Indonesia, Jurnal Magister Hukum Udayana, Vo. 6 No. 3, https://ojs.unud.ac.id/index.php/jmhu/article/view/36110/22070, diakses tanggal 29 Mei 2019. h. 1.

${ }^{7}$ Hendrik Budi Untung, op.cit, h. 54.
} 


\subsection{Tujuan Penelitian}

Tujuan peneltian ini adalah untuk mengetahui bentuk perizinan penggunaan TKA dalam Perpres No. 20 Tahun 2018 dan mengetahui apakah ketentuan terkait perizinan penggunaan TKA dalam Perpres tersebut telah sesuai dengan peraturan dasarnya yakni UU No. 13 Tahun 2003.

\section{Isi Makalah}

\subsection{Metode Penelitian}

Penyusunan penelitian ini menggunakan metode penelitian hukum normatif, yakni suatu metode penelitian hukum yang meneliti hukum dari perspektif internal yang objek penelitiannya adalah norma hukum, untuk memberikan argumentasi ketika terdapat norma kosong, noma kabur, maupun konflik norma. ${ }^{8}$ Adapun pendekatan yang digunakan dalam penyusunan penelitian ini adalah pendekatan undang-undang, yakni pendekatan yang menjadikan peraturan perundang-undangan sebagai dasar dalam melakukan kajian. ${ }^{9}$

\subsection{Hasil dan Analisis}

\subsubsection{Pengaturan izin penggunaan TKA dalam Perpres No. 20 Tahun 2018}

Penempatan TKA di Indonesia memiliki beberapa tujuan, beberapa diantaranya adalah sebagai upaya pemenuhan kebutuhan

8 I Made Pasek Diantha, 2017, Metodologi Penelitian Hukum Normatif, Prenada Media Group, Jakarta, h. 12.

${ }^{9}$ Hajar, 2017, Model-Model Pendekatan Dalam Penelitian Hukum \& FIQH, Kalimedia, Yogyakarta, h. 68. 
tenaga kerja ahli, sebagai upaya peningkatan investasi asing dan sebagai upaya untuk melakukan proses alih ilmu pengetahuan atau alih teknologi. ${ }^{10}$ H.S Syarif menyatakan bahwa penempatan TKA di Indonesia saat ini dan di waktu yang akan datang akan tetap dibutuhkan karena didasarkan pada beberapa hal, yakni erat kaitannya dengan penanaman modal yang dilakukan oleh investor, pengoperasian alat-alat canggih yang perlu ditangani oleh ahlinya, meluasnya bidang usaha yang memerlukan tenaga kerja ahli dan kebijakan indonesianisasi yang belum dapat diterapkan secara maksimal karena perlu TKI yang terkualifikasi ahli untuk menggantikan TKA. ${ }^{11}$

Membahas mengenai perizinan penggunaan TKA di Indonesia, sebelum lahirnya Perpres No. 20 Tahun 2018 dan peraturan turunannya yakni Peraturan Menteri Ketenagakerjaan No. 10 Tahun 2018 Tentang Tata Cara Penggunaan Tenaga Kerja Asing (selanjutnya disingkat Permen Ketenagakerjaan No. 10 Tahun 2018), pengaturan terkait perizinan penggunaan TKA didasarkan pada Peraturan Presiden No. 72 Tahun 2014 Tentang Penggunaan Tenaga Kerja Asing Serta Pelaksanaan Pendidikan Dan Pelatihan Tenaga Kerja Pendamping (selanjutnya disingkat Perpres No. 72 Tahun 2014) dan peraturan turunannya yakni Peraturan Menteri Ketenagakerjaan No. 16 Tahun 2015 Tentang Tata Cara Penggunaan Tenaga Kerja Asing (selanjutnya disingkat Permen Ketenagakerjaan No. 16 Tahun 2015). Peraturan-peraturan tersebut merupakan peraturan pelaksana ketentuan Pasal 49 UU No. 13 Tahun 2003.

${ }^{10}$ Abdul Rachmad Budiono, 1999, Hukum Perburuhan Di Indonesia, PT RajaGrafindo Persada, Jakarta, h. 265.

${ }^{11}$ Ibid. 
Berikut adalah uraian tahapan perizinan penggunaan TKA berdasarkan Perpres No. 72 Tahun 2014 :

1. Pemberi kerja yang akan mempekerjakan TKA harus memiliki RPTKA $^{12}$ yang telah disahkan Menteri atau pejabat yang ditunjuk. RPTKA diperoleh dengan mengajukan permohonan serta mengunggah syarat-syarat tertentu secara online. RPTKA adalah dasar untuk mendapatkan IMTA ${ }^{13}$.

2. Apabila permohonan RPTKA telah lengkap maka akan dilakukan penilaian kelayakan, apabila permohonan tidak lengkap maka petugas akan memberi tahu pemberi kerja secara online terkait kekurangan dokumen.

3. Dalam jangka waktu paling lama tiga hari, Dirjen atau direktur mengeluarkan keputusan pengesahan RPTKA setelah dilakukannya proses penilaian kelayakan RPTKA.

4. Setelah mendapat pengesahan RPTKA, pemberi kerja TKA wajib memiliki IMTA. IMTA diperoleh dengan mengajukan permohonan serta mengunggah syarat-syarat tertentu secara online. Setelah permohonan IMTA memenuhi persyaratan yang telah ditentukan, dalam jangka waktu paling lama tiga hari kerja IMTA tersebut akan diterbitkan.

Setelah keluarnya Perpres No. 20 Tahun 2018, terkait perizinan penggunaan TKA mengalami beberapa perubahan yang tahapannya dapat diuraikan sebagai berikut:

${ }^{12}$ RPTKA atau Rencana Penggunaan Tenaga Kerja Asing adalah rencana penggunaan TKA pada jabatan tertentu yang dibuat oleh pemberi kerja untuk jangka waktu tertentu yang disahkan oleh Menteri atau pejabat yang ditunjuk. RPTKA merupakan dasar untuk memperoleh IMTA.

${ }^{13}$ IMTA atau Izin Mempekerjakan TKA adalah izin tertulis yang diberikan Menteri atau pejabat yang ditunjuk kepada pemberi kerja TKA. 
1. Pemberi kerja yang akan mempekerjakan TKA harus memiliki RPTKA yang telah disahkan Menteri atau pejabat yang ditunjuk. RPTKA diperoleh dengan mengajukan permohonan serta mengunggah syarat-syarat tertentu secara online. RPTKA merupakan izin mempekerjakan TKA.

2. Apabila permohonan RPTKA telah lengkap maka akan dilakukan penilaian kelayakan, apabila permohonan tidak lengkap maka petugas akan memberi tahu pemberi kerja secara online terkait kekurangan dokumen.

3. Dalam jangka waktu paling lama dua hari, Dirjen atau direktur menerbitkan pengesahan RPTKA setelah penilaian terhadap kelayakan RPTKA dilakukan.

4. Selain RPTKA pemberi kerja TKA juga wajib melakukan permohonan Notifikasi ${ }^{14}$ sebagai bentuk persetujuan penggunaan TKA yang diterbitkan oleh Dirjen Pembinaan Penempatan Tenaga Kerja dan Perluasan Kesempatan Kerja. Permohonan Notifikasi dilakukan dengan mengisi data calon TKA secara online yang selanjutnya akan diverifikasi. Apabila data yang diunggah kurang lengkap maka direktur menyampaikan kepada pemberi kerja TKA terkait kurangnya data, apabila sudah lengkap maka Dirjen menerbitkan Notifikasi secara online paling lama 2 hari kerja.

Jadi, berdasarkan uraian tahapan-tahapan perizinan di atas terlihat adanya penyederhanaan bentuk perizinan dalam Perpres No. 20 Tahun 2018. Berdasarkan Pasal 9 Perpres No. 20 Tahun 2018, RPTKA merupakan suatu izin untuk mempekerjakan TKA.

${ }^{14}$ Notifikasi adalah persetujuan penggunaan TKA yang diterbitkan oleh Direktur Jenderal Pembinaan Penempatan Tenaga Kerja dan Peluasan Kesempatan Kerja. 
Sebelumnya izin untuk mempekerjakan TKA adalah IMTA dan pengesahan RPTKA merupakan persyaratan awal untuk memperoleh IMTA sebagaimana diatur dalam Pasal 5 Ayat 1 dan 3 Perpres No. 72 Tahun 2014. Disamping itu, pada Perpres No. 20 Tahun 2018 terlihat adanya komponen perizinan baru yakni Notifikasi sebagai bentuk persetujuan penggunaan TKA (Pasal 14 Ayat 3 Perpres No. 20 Tahun 2018).

Perbedaan terkait perizinan penggunaan TKA juga terlihat pada aturan turunan dari kedua Peraturan Presiden diatas, berikut adalah perbedaan antara Permen Ketenagakerjaan No. 10 Tahun 2018 dengan Permen Ketenagakerjaan No. 16 Tahun 2015:

1. Dilihat dari segi waktu proses perizinannya. Dalam Permen Ketenagakerjaan No. 10 Tahun 2018 proses penerbitan RPTKA maupun Notifikasi berlangsung masing-masing paling lama dua hari (Pasal 11 Ayat 7 dan Pasal 19 Ayat 5). Pada Permen Ketenagakerjaan No. 16 Tahun 2015 proses penerbitan RPTKA dan IMTA berlangsung masing-masing paling lama tiga hari (Pasal 8 dan Pasal 39 Ayat 1).

2. Dilihat dari segi jangka waktu berlakunya izin. Pada Permen Ketenagakerjaan No. 10 Tahun 2018 masa berlakunya RPTKA dan Notifikasi adalah sesuai dengan perjanjian kerja (Pasal 9 Ayat 2 dan Pasal 19 Ayat 7), sedangkan pada Permen Ketenagakerjaan No. 16 Tahun 2015 RPTKA memiliki jangka waktu berlaku adalah paling lama lima tahun dan IMTA paling lama satu tahun (Pasal 12 dan Pasal 39 Ayat 2).

3. Pada Permen Ketenagakerjaan No. 10 Tahun 2018 terdapat pengecualian kepemilikan RPTKA bagi pemberi kerja yang mempekerjakan TKA sebagai anggota direksi atau anggota dewan 
komisaris dengan kepemilikan saham (Pasal 10 Ayat 1 huruf b). Sebelumnya pada Permen Ketenagakerjaan No. 16 Tahun 2015 pemberi kerja yang dikecualikan dari kepemilikan RPTKA adalah pemerintah, badan dan organisasi internasional, perwakilan dan kantor perwakilan diplomatik, dan badan usaha asing (Pasal 6 Ayat 3).

4. Pada Permen Ketenagakeraan No. 10 Tahun 2018 terdapat 3 sektor baru untuk rangkap jabatan yang diperbolehkan bagi TKA selain direktur atau komisaris yang bukan pemegang saham, yaitu bidang pendidikan pelatihan vokasi, sektor ekonomi digital, serta sektor migas bagi kontraktor kontrak kerja sama (Pasal 8 Ayat 1 huruf b). Sebelumnya rangkap jabatan hanya diperbolehkan untuk TKA anggota direksi, anggota dewan komisaris, anggota pengurus atau pengawas berdasarkan RUPS atau Rapat Pembina (Permen Ketenagakerjaan No. 16 Tahun 2015 Pasal 41 ayat 3).

\subsubsection{Perizinan penggunaan TKA berdasarkan Perpres No. 20 Tahun 2018 apabila dikaji berdasarkan perspektif UU No. 13 Tahun 2003}

Dikaji berdasarkan perspektif UU No. 13 Tahun 2003, pemberi kerja yang akan mempekerjakan TKA harus memiliki izin tertulis serta wajib memiliki RPTKA sebagaimana diatur dalam Pasal 42 Ayat 1 dan Pasal 43 Ayat 1. Ketentuan penjelasan Pasal 43 Ayat 1 UU No. 13 Tahun 2003 menyatakan bahwa RPTKA adalah syarat untuk memperoleh izin mempekerjakan TKA. Pada Pasal 9 Perpres No. 20 Tahun 2018, RPTKA dinyatakan sebagai izin untuk mempekerjakan TKA dan Perpres No. 20 Tahun 2018 menghilangkan komponen IMTA yang sebelumnya diatur dalam Perpres No. 72 Tahun 2014. RPTKA 
menurut UU No. 13 Tahun 2003 bukanlah merupakan suatu izin, tetapi merupakan suatu syarat untuk mendapat izin kerja, izin kerja yang dimaksud adalah IMTA. Jadi berdasarkan hal tersebut ketentuan terkait RPTKA pada Perpres No. 20 Tahun 2018 berlawanan dengan ketentuan Pasal 43 ayat 1 dalam UU No. 13 Tahun 2003.

Ketentuan Pasal 10 Ayat 1 huruf a dalam Perpres No. 20 Tahun 2018 juga berlawanan dengan ketentuan Pasal 43 Ayat 3 UU No. 13 Tahun 2003. Pasal 10 Ayat 1 huruf a dalam Perpres No. 20 Tahun 2018 tersebut menjelaskan mengenai pengecualian kepemilikan RPTKA tehadap pemberi kerja apabila mempekerjakan TKA yang menjabat sebagai anggota direksi atau anggota dewan komisaris dengan kepemilikan saham, sedangkan dalam Pasal 43 Ayat 3 UU 13 Tahun 2003 pemberi kerja yang dikecualikan dari kewajiban memiliki RPTKA hanya diberikan untuk pemerintah, badan internasional, dan perwakilan diplomatik. Jadi, terlihat ketentuan Pasal 10 Ayat 1 huruf a dalam Perpres No. 20 Tahun 2018 tersebut memperluas pengecualian kewajiban memiliki RPTKA yang diatur dalam UU No. 13 Tahun 2003.

Ditinjau berdasarkan hirarki Peraturan Perundang-undangan letak Peraturan Presiden berada dibawah Undang-Undang, maka seharusnya ketentuan dalam Perpres No. 20 Tahun 2018 tidak boleh berlawanan dengan ketentuan dalam UU No. 13 Tahun 2003 selaku peraturan yang kedudukannya lebih tinggi. Berdasarkan asas Lex Superior derogat legi Inforiori, peraturan yang memiliki kedudukan lebih tinggi akan mengesampingkan peraturan yang lebih rendah 
kedudukannya ${ }^{15}$. Jadi, ketentuan terkait izin mempekerjakan TKA akan mengacu pada UU No. 13 Tahun 2003 selaku peraturan yang lebih tinggi.

\section{Penutup}

\subsection{Kesimpulan}

Berdasarkan pemaparan analisis diatas, berikut kesimpulan yang penulis simpulkan:

1. Terdapat penyederhanaan bentuk perizinan penggunaan TKA dalam Perpres No. 20 Tahun 2018, yakni diantaranya adalah perbedaan penetapan RPTKA sebagai izin kerja, waktu proses pengurusan izin yang dikurangi, perubahan jangka waktu berlakunya RPTKA dan Notifikasi yang didasarkan pada Perjanjian Kerja, penambahan pengecualian kepemilikan RPTKA bagi pemberi kerja TKA dan penambahan 3 sektor baru rangkap jabatan bagi TKA.

2. Ketentuan pada Pasal 9 yang mengatur mengenai penetapan RPTKA sebagai izin mempekerjakan TKA dan Pasal 10 Ayat 1 huruf a yang mengatur mengenai pengecualian kepemilikan RPTKA tehadap pemberi kerja apabila mempekerjakan TKA yang menjabat sebagai anggota direksi atau anggota dewan komisaris dengan kepemilikan saham dalam Perpres No. 20 Tahun 2018 bertentangan dengan ketentuan yang diatur UU No. 13 Tahun 2003 yakni Pasal 43 Ayat 1 dan Pasal 43 Ayat 3.

\subsection{Saran}

\footnotetext{
${ }^{15}$ Muhammad Sadi, 2015, Pengantar Ilmu Hukum, Prenadamedia Group, Jakarta, h. 160.
} 
Beberapa ketentuan terkait izin mempekerjakan TKA dalam Perpres No. 20 Tahun 2018 seharusnya disesuaikan dengan ketentuan dalam UU No. 13 Tahun 2003 mengingat kedudukan UU No. 13 Tahun 2003 yang lebih tinggi. Jadi, dengan dilakukannya penyesuaian diharapkan dapat memberikan kepastian hukum di bidang ketenagakerjaan khususnya terkait aturan tentang izin penggunaan TKA.

\section{Daftar Pustaka}

\section{Buku-buku :}

Abdul Khakim, 2014, Dasar-Dasar Hukum Ketenagakerjaan Indonesia, PT Citra Aditya Bakti, Bandung.

Abdul Rachmad Budiono, 1999, Hukum Perburuhan Di Indonesia, PT RajaGrafindo Persada, Jakarta.

Hajar, 2017, Model-Model Pendekatan Dalam Penelitian Hukum \& FIQH, Kalimedia, Yogyakarta.

Hendrik Budi Untung, 2017, Hukum Investasi, Sinar Grafika, Jakarta.

I Made Pasek Diantha, 2017, Metodologi Penelitian Hukum Normatif, Prenada Media Group, Jakarta.

I Made Udiana, 2016, Kedudukan Dan Kewenangan Pengadilan Hubungan Industrial, Udayana University Press, Denpasar.

I Made Udiana, 2018, Industrialisasi Dan Tanggungjawab Pengusaha Terhadap Tenaga Kerja Terlibat Hukum, Udayana University Press, Denpasar.

Muhammad Sadi, 2015, Pengantar Ilmu Hukum, Prenadamedia Group, Jakarta. 


\section{Jurnal Ilmiah :}

Noor Faiz, 2017, Korelasi Pengaturan Upah Dengan Investasi Di Indonesia, Jurnal Magister Hukum Udayana, Vol. 6, No. 3, https://ojs.unud.ac.id/index.php/jmhu/article/view/36110/22 070, diakses tanggal 29 Mei 2019.

Putu Tuni Cakabawa Landra, 2018, Hukum Investasi Dalam Industrialisasi Kepariwisataan Bali, Jurnal Magister Hukum Udayana, Vol.7 , No. https://ojs.unud.ac.id/index.php/jmhu/article/view/37685/24 230, diakses tanggal 29 Mei 2019.

\section{Peraturan Perundang-Undangan :}

Undang-Undang Republik Indonesia Nomor 13 Tahun 2003 Tentang Ketenagakerjaan (Lembaran Negara Republik Indonesia Tahun 2003 Nomor 39, Tambahan Lembaran Negara Republik Indonesia Nomor 4279)

Peraturan Presiden Republik Indonesia Nomor 20 Tahun 2018 Tentang Penggunaan Tenaga Kerja Asing (Lembaran Negara Republik Indonesia Tahun 2018 Nomor 39)

Peraturan Presiden Republik Indonesia Nomor 72 Tahun 2014 Tentang Penggunaan Tenaga Kerja Asing Serta Pelaksanaan Pendidikan Dan Pelatihan Tenaga Kerja Pendamping (Lembaran Negara Republik Indonesia Tahun 2014 Nomor 162)

Peraturan Menteri Ketenagakerjaan Republik Indonesia Nomor 10 Tahun 2018 Tentang Tata Cara Penggunaan Tenaga Kerja Asing (Berita Negara Republik Indonesia Tahun 2018 Nomor 882)

Peraturan Menteri Ketenagakerjaan Republik Indonesia Nomor 16 Tahun 2015 (Berita Negara Republik Indonesia Tahun 2015 Nomor 964) 